\title{
Spontaneous Subdural Hematoma Associated with Kasabach-Merritt Syndrome: A Case Report
}

\author{
Kasabach-Merritt Sendromu ile İlişkili Spontan Subdural Hematom: \\ Bir Olgu Sunumu
}

\author{
Ufuk Emre $^{1}$, Ayla Gökmen ${ }^{2}$, Banu Özen ${ }^{1}$, Enes Demiryürek ${ }^{1}$, Şanser Gül ${ }^{3}$, Dilvin Gökçe ${ }^{4}$ \\ ${ }^{1}$ Bülent Ecevit University, School of Medicine, Department of Neurology, Zonguldak, Turkey \\ ${ }^{2}$ Bülent Ecevit University, School of Medicine, Department of Hematology, Zonguldak, Turkey \\ ${ }^{3}$ Bülent Ecevit University, School of Medicine, Department of Neurosurgery, Zonguldak, Turkey \\ ${ }^{4}$ Zonguldak Ataturk State Hospital, Zonguldak, Turkey
}

\section{To the Editor,}

Kasabach-Merritt syndrome (KMS) is characterized by consumption coagulopathy (thrombocytopenia, anemia, hypofibrinogenemia, and high D-dimer level), angioma, and kaposiform hemangioendothelioma [1-3]. Herein we present the first reported case of spontaneous subdural hematoma associated with KMS. Written informed consent was obtained from the patient.

A 24-year-old female with KMS was referred to our hospital with a subdural hematoma. Persistent, severe headache and neck pain began 10 days earlier, and she had a negative history of trauma. She had migraine without aura, psoriasis, and KMS. KMS was diagnosed at another medical center. Her general physical examination showed large cutaneous hemangiomas in her extremities, with left side predominance. Two fingers on her left hand had been amputated. Her neurological examination was normal. Blood analysis findings were thrombocytopenia (platelet count: $87 \times 10^{9} / \mathrm{L}$ ), hypofibrinogenemia, and a high D-dimer level (5000 ng/ mL [normal: $147 \mathrm{ng} / \mathrm{mL}$ ]). The fibrinogen level was $40 \mathrm{mg} / \mathrm{dL}$ (normal range: 175-400 $\mathrm{mg} / \mathrm{dL}$ ). Other hemogram parameters (hemoglobin level: $12.6 \mathrm{~g} / \mathrm{dl}$, white blood cell count: $6.1 \times 10^{9} / \mathrm{L}$, hematocrit level: $36.1 \%)$ and laboratory findings were normal. Cranial MRI showed a bilateral subacute subdural hematoma in the frontotemporoparietal region and subacute hemor- rhage in the right tentorial region (Figure A-C). Fresh frozen plasma ( 3 units) was administered to treat hypofibrinogenemia within 3 days after admission, and the patient was given bed rest with head elevated for 15 days.Amitriptyline and analgesic drugs were initiated from the first day of admission. Two months later after discharge from hospital, she did not state any complaints and cranial CT showed a reduction in the size of the subdural hematoma.

Central nervous system involvement in KMS is rare. A search of the literature showed that there are no reports of intracranial bleeding as a complication of KMS. In the presented case cranial MRI did not show a hemangioma or tumoral lesion in the parenchymal region, but did show a large bilateral subdural hematoma. In patients with a subdural hematoma imaging findings (hematoma volume, degree of midline shift, and compression of the brainstem) and neurological examination (low Glasgow Coma Scale score) may help indicate prognosis and appropriate treatment options (surgery or medical) [4]. In the presented case surgical treatment wasn't considered because hematoma size didn't increase and patient's clinic did not deteriorate during follow-up. Corticosteroid is considered the first-line therapy for KMS-either high-dose methylprednisolone (30 $\mathrm{mg} / \mathrm{kg}$ for $3 \mathrm{~d}$, followed by dose tapering) or oral corticosteroid (2-5 mg/kg per day), and intravenous corticosteroid may be more efficacious than oral cortico-

Address for Correspondence: Ufuk EMRE, M.D.,

Bülent Ecevit Üniversitesi, Tıp Fakültesi, Nöroloji Anabilim Dalı, Zonguldak, Turkey

Phone: +90 3722610169 E-mail: ufuemr@gmail.com

Received/Gelis tarihi : October 22, 2011

Accepted/Kabul tarihi : March 6, 2012 


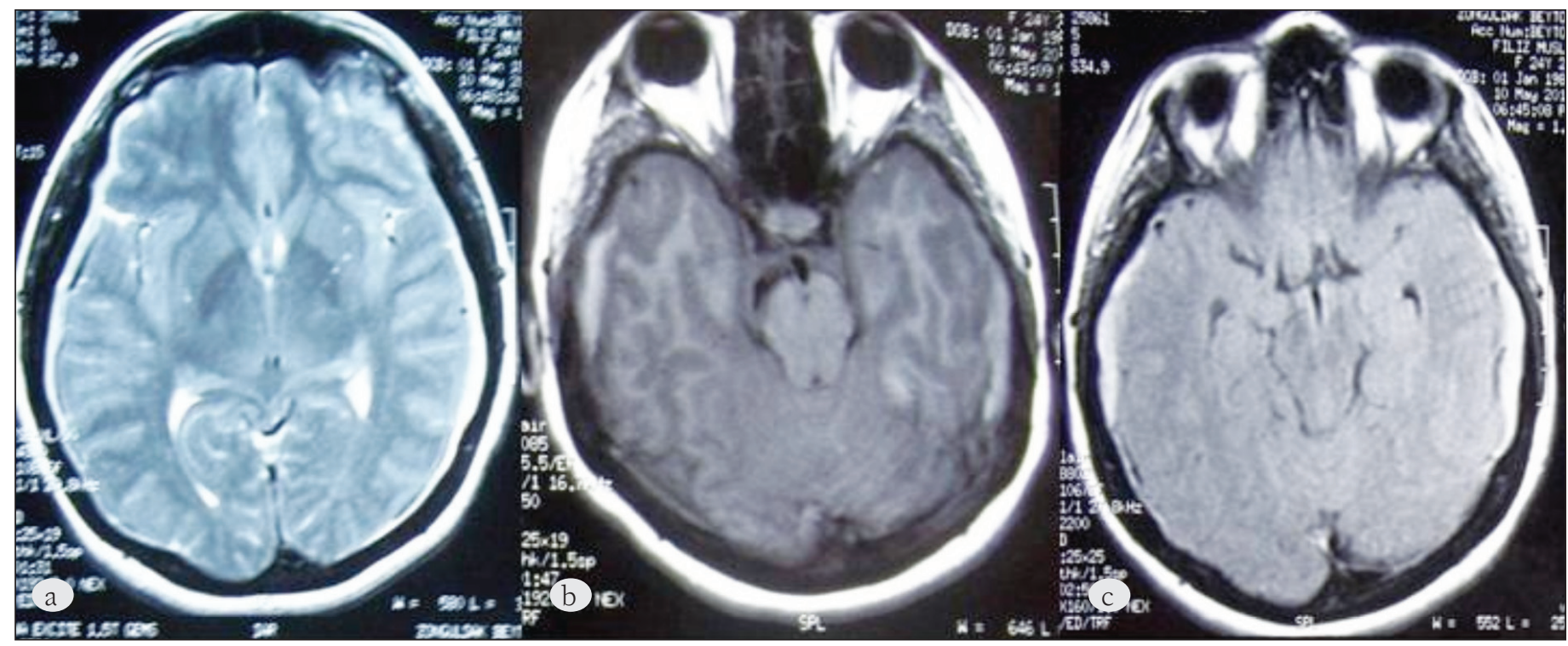

Figure : The cranial magnetic resonance imaging revealed bilateral subacute subdural haematomas in the frontotemporoparietal region on axial T2-weighted image (a), T1-weighted (b), FLAIR image (c) respectively.

steroid [5]. Alfa-IFN-2a and chemotherapeutic agents are used to prevent tumor expansion $[1,5]$. Packed red cells, fresh frozen plasma, cryoprecipitate, and pentoxifyline may be considered for treatment [6]. Fresh frozen plasma $(15 \mathrm{~mL} / \mathrm{kg})$ is recommended in patients with prolonged clotting time and generalized bleeding, and prior to invasive procedures [2]. Surgical excision, embolization, and radiotherapy can be used in appropriate patients [1,2]. The presented patient received medical therapy based on the clinical findings. In conclusion, the present case report is the first to describe a subdural hematoma in a KMS patient; thus, KMS should be considered in the differential diagnosis of patients with intracranial hemorrhage.

\section{Conflict of Interest Statement}

None of the authors has any conflicts of interest, including specific financial interests, relationships, and/or affiliations, relevant to the subject matter or materials included.

\section{References}

1. Maguiness S, Guenther L. Kasabach-Merritt syndrome. J Cutan Med Surg 2002; 6 (4): 335-339

2. Hall GW. Kasabach-Merritt Syndrome: Pathogenesis And Management. Br J Haematol 2001; 112: 851-862

3. Mizuno J, Nakagawa H, Watabe T, Sugimoto I. Spontaneous spinal epidural haematoma in association with KasabachMerritt syndrome. J Clin Neurosci 1999; 6: 518-520

4. Dent DL, Croce MA, Menke PG, Young BH, Hinson MS, Kudsk KA, Minard G, Pritchard FE, Robertson JT, Fabian TC. Prognostic factors after acute subdural hematoma. J Trauma 1995; 39: 36-42

5. Ryan C, Price V, John P, Mahant S, Baruchel S, Brandão L, Blanchette V, Pope E, Weinstein M. Kasabach-Merritt phenomenon: A single centre experience Miriam Weinstein. Eur J Haematol 2010; 84: 97-104

6. Sarkar M, Mulliken JB, Kozakewich HP, Robertson RL, Burrows PE. Thrombocytopenic coagulopathy (KasabachMerritt Phenomenon) is associated with Kaposiform hemangioendothelioma and not with common infantile hemangioma. Plas Reconstr Surg 1997; 100: 1377-1386 